\title{
Quality of life related with health and academic satisfaction of university students
}

\section{Calidad de vida relacionada con la salud y satisfacción académica de estudiantes universitarios}

GARCÍA-GARCÍA, Jesús Alberto†*, CUFARFÁN-LÓPEZ, Julio, FARIAS-BRACAMONTES, Juan Carlos and GARCÍA-CONTRERAS, Laura Patricia

Universidad Autónoma de Coahuila-Facultad de Ciencia, Educación y Humanidades

ID $1^{\text {st }}$ Author: Jesús Alberto, García-García / ORC ID: 0000-0003-1369-311X, Researcher ID Thomson: D-8211-2019, CVU CONACYT ID: 568438

ID $1^{\text {st }}$ Coauthor: Julio, Cufarfán-López / ORC ID: 0000-0001-7203-8022, CVU CONACYT ID: 201670

ID $2^{\text {nd }}$ Coauthor: Juan Carlos, Farías-Bracamontes

ID $3^{\text {rd }}$ Coauthor: Laura Patricia, García-Contreras

DOI: $10.35429 /$ EJRG.2020.6.10.24.30

Received March 10, 2020; Accepted June 08, 2020

\section{Resumen}

El objetivo de este artículo fue explorar las dimensiones de calidad de vida relacionada con la salud y la satisfacción académica de estudiantes universitarios. La metodología que se utilizó fue cuantitativa, observacional, transversal, prospectiva, descriptiva y correlacional. La recopilación de la información se realizó a través de una batería conformada por 2 escalas; a) el cuestionario SF-12 y la escala de Satisfacción Académica. La muestra se conformó por 467 estudiantes, el método de muestreo que se utilizó fue no probabilístico, mediante la estrategia de muestreo por conveniencia. Las técnicas estadísticas que se utilizaron fueron la estadística descriptiva y correlacional. La contribución del estudio radica en la evidencia empírica estadística que permite afirmar que las dimensiones de rol físico, rol emocional y vitalidad favorecen la satisfacción académica de los universitarios. Sí los estudiantes se perciben cómodos con su atmosfera escolar, disfrutan sus actividades escolares y se sienten entusiasmados con los temas de su especialización, tendrán mejor salud física y mental.

Calidad de vida relacionada con la salud, Satisfacción académica, Universitarios

\begin{abstract}
The aim of this article was to explore the dimensions of quality of life related to health and academic satisfaction of university students. The methodology used was quantitative, observational, cross-sectional, prospective, descriptive and correlational. The compilation of the information was carried out through a battery made up of two scales; a) the SF-12 questionnaire and the Academic Satisfaction scale. The sample consisted of 467 students, the sampling method that was used was non-probabilistic, through the convenience sampling strategy. The statistical techniques that were used were descriptive and correlational statistics. The contribution of the study lies in the statistical empirical evidence that allows affirming that the dimensions of physical role, emotional role and vitality favor the academic satisfaction of university students. If students feel comfortable with their school atmosphere, enjoy their school activities, and are enthusiastic about their majors, they will have better physical and mental health.
\end{abstract}

Quality of life related to health, Academic satisfaction, University students

Citation: GARCÍA-GARCÍA, Jesús Alberto, CUFARFÁN-LÓPEZ, Julio, FARIAS-BRACAMONTES, Juan Carlos and GARCÍA-CONTRERAS, Laura Patricia. Quality of life related with health and academic satisfaction of university students ECORFAN Journal-Republic of Guatemala. 2020, 6-10: 24-30

\footnotetext{
* Correspondence to Author (email: jegarciag@ uadec.edu.mx)

$\uparrow$ Researcher contributing first author.
} 


\section{Introduction}

The study of the Quality of Life is increasingly relevant, the health crisis caused by the COVID19 , exposed the shortcomings of the health system worldwide, as well as the main diseases that caused the death of millions of people. The general population faces health problems related to different social, cultural, economic, political and educational factors. Students are a vulnerable sector of the population that faces risk situations that must be analyzed in order to achieve solutions from the school context. The central problem is that university students have little awareness of their health care and lifestyle, combined with low levels of academic satisfaction and school performance.

Health-related quality of life is shaped by dimensions such as physical function, physical role, body pain, general health, vitality, social function, emotional role, and mental health. While academic satisfaction involves the wellbeing and enjoyment that students perceive in carrying out experiences related to their role as students (Lent \& Brown, 2008). It has been defined as the degree of congruence between students' expectations and the results obtained in the learning process (Candelas, Gurruchaga, Mejias \& Flores, 2013).

The hypothesis of this study is the following: if there are high levels of healthrelated quality of life then students will show greater academic satisfaction.

From the review of the literature it was found that there is research oriented to evaluate the health-related quality of life in children and adolescents and few works that evaluate the relationship between HRQOL and academic satisfaction, for this reason this article presents added value for its approach and for the relevance of quantitatively analyzing the study variables.

Therefore, the objective of this article was to explore the dimensions of quality of life related to health and academic satisfaction of university students. The structure of the article is made up of the following sections: first, a review of the literature on HRQOL and school satisfaction in university population is presented, then the methodology of the study, participants, design and instruments used are explained.
Then the statistical results are presented to contrast the central hypothesis and finally the main conclusions of the study are presented.

\section{Literature Review}

The issue of quality of life related to health is relevant because of its social significance, as long as people are healthy and have welfare, social problems will decrease. In the context of the University, these have a great responsibility and social commitment, because in them the future citizens are formed, for that reason it is fundamental that the students have an education of quality and reach the greater possible academic satisfaction. In fact, the university space is recognized as a privileged setting that favors health and contributes to the development of the potential of each individual, as well as the collective that makes up the university community (Reig, Cabrero, Ferrer, \& Richart, 2001). Academic satisfaction is a construct that will explain different educational variables that are relevant to the integral development of studies. And according to Vergara, Del Valle, Diaz, \& Pérez, (2018) it constitutes a key aspect to explain the quality of learning.

The results obtained by Cassaretto, Martínez, \& Tavera, (2020) affirm that significant differences exist between the levels of physical health and those of mental health. It was found that physical health is significantly higher than mental health. In the area of health best evaluated in the participants was physical function, which implies that students do not suffer from health problems that interfere significantly with their daily physical activities such as self-care, walking or climbing stairs. On the other hand, the weakest health dimensions are vitality and emotional role, indicating that energy and vitality are the most affected aspect of students' health, followed by limitations in their emotional health in work and other daily activities.

In addition, $32.9 \%$ of university students had a less favorable quality of life, with women being 4.4 times more likely than men. Students who rated their quality of life "moderately or less favorable" had differences in relation to those who had a favorable opinion. There was a high association of quality of life with biological, behavioral, and social problems (Pacheco, Michelena, Mora, \& Miranda, 2014). 
On the other hand Terrazas \& Almeida, (2020), identified the level of incidence of academic and social aspects in the quality of university life, the Bolivian Catholic University and the Del Valle Private University presented a significant relationship, that is, that academic and social aspects influenced positively in the quality of university life, the educational programs implemented by the universities, the teaching and the academic reputation are the most relevant indicators for a good university quality, on the other hand, the identification of those elements that are more outstanding for the students, allows to incorporate their opinions in the quality system.

Academic satisfaction is reported in the literature with different meanings, satisfaction with university life, student or school satisfaction. School satisfaction has been defined as a cognitive-affective evaluation of school experiences (Luna, 2012). In this way, the structure, organization, curriculum, resources, evaluation system, and even the uses and customs of the school institution can come into conflict with the expectations and goals of students, affecting their school satisfaction and, probably, their academic performance (Pascual, 2007).

Since satisfaction was a key component, it began to be incorporated into the educational context, since it was determined that student satisfaction in the school environment was an important variable in academic success (Escobar \& Rodriguez, 2018).

The academic, cultural and sports activities, the relationships with teachers and classmates, the satisfaction of the students with their studies and with the quality of the teaching and the different services offered by the University, constitute the context in which an important part of the life of young university students takes place and requires to be studied, first, to know their influence or relationship with their health and quality of life and, second, to identify those aspects that require attention by the institution through policies and actions that promote a healthy environment and contribute to the welfare of the university community (Lara, Saldaña, Fernández, \& Delgadillo, 2015).
The CVRS research and academic satisfaction allows us to deduce that the quality of university life is determined in a very similar way by both the satisfaction with the teaching aspects and the satisfaction with the social aspects (Blázquez, Chamizo, Cano, \& Gutiérrez, 2013). Likewise, students who were more satisfied with their studies had better relationships with their classmates, valued the quality of teaching as good and very good, and used sports facilities more, had a better perception of their quality of life (Lara et al., 2015).

On the other hand, 10 variables were analyzed as predictors, and five were statistically significant, which together explain $36 \%$ of the variance in school satisfaction. The model was shaped by: I like going to school, my teachers treat me well, I feel safe at school, I am satisfied with my classmates and I am satisfied with the experience at school. These last two variables are the best predictors of school satisfaction (Alfaro et al., 2016).

In terms of the type of school (modality), it is observed that students in private and technical schools have a higher quality of school life than those who attend general, telesecondary, and indigenous schools. Students attending the latter have the lowest quality of school life (Escobar \& Rodríguez, 2018).

Academic satisfaction shows a slight trend toward high levels. It was found that the greater the academic self-efficacy and the lesser the emotional burnout, the greater the academic satisfaction (Morales \& Chávez, 2019).

The results show that there is a positive correlation between teacher emotional intelligence and student academic satisfaction. Likewise, it is observed that the correlation between academic satisfaction and the interpersonal component (interpersonal relationships, social responsibility and empathy) is greater with respect to the correlations with the other components (Tacca, Tacca, \& Cuarez, 2020).

With respect to the students' perception of the university environment, they state that teachers work with professionalism $48.0 \%$, teacher accessibility $44.5 \%$ (207), administrative personnel attend to students' needs $43.7 \%$, and the university has recreational and cultural spaces $42.2 \%$.

GARCÍA-GARCÍA， Jesús Alberto， CUFARFÁN-LÓPEZ， Julio, FARIAS-BRACAMONTES, Juan Carlos and GARCÍACONTRERAS, Laura Patricia. Quality of life related with health and academic satisfaction of university students ECORFAN JournalRepublic of Guatemala. 2020 
In terms of their $\mathrm{CV}$, it can be seen that in general, physical health has the best evaluation $(76.9 \%)$ against mental health with $66.6 \%$. It seems that the physical or organic component is better evaluated by the subjects, which corresponds to the dimension of physical functioning that has the highest and most positive evaluation of all $(93.3 \%)$. While the energy or fatigue dimension is the lowest of all $(58.1 \%)$ and may be affecting the perception of mental health. In addition, the dimension of emotional problems, which is related to mental health, is the one with the greatest dispersion on the entire scale, indicating that the students in this sample present great differences on an emotional level, that is, some are very good and others are very bad. As for general physical and mental health in university students, it is observed that physical health presents better indicators than mental health (Brito \& Palacio, 2016).

The results indicate that the highest values were obtained in the dimensions corresponding to CSF, with the physical function dimension showing the highest score. This suggests that university students have a favorable perception of their health at the physical level. On the other hand, in relation to the differences according to sex in the dimensions of perceived physical and mental health, men obtained higher scores in the CSF and in the dimensions that make up the CSF, with the exception of the physical role dimension. On the other hand, with regard to the differences according to sex in the dimensions of perceived physical and mental health, men obtained higher scores in the CSF and in the dimensions that comprise it, with the exception of the physical role dimension. (Chau \& Vilela, 2017).

Boys had higher scores in the VC indices ( $\mathrm{p}<0.05)$, except for social VC $(\mathrm{p}=0.830)$ and school VC. In the latter, girls presented a slightly higher score $(\mathrm{p}=0.843)$ (Lima, Martínez, Guerra, Vargas, \& Lima, 2018).

An association was found between low academic performance, being an adolescent, and compromised social relations, which in the long run may compromise their HRQoL (Díaz, Martínez, \& Zapata, 2017).

\section{Methodology}

\section{Design}

The type of research is quantitative, with a transversal, open, observational and descriptive design (Méndez, Namihira, Moreno \& Sosa, 1990).

\section{Participants}

The selection of the sample was made in a nonprobabilistic way; the strategy used was the sampling by convenience, the total of the sample was of 467 students. According to gender, $48 \%$ are women and $52 \%$ are men. The average age was 20 years. $74 \%$ of the university students do not smoke, while $24 \%$ do, $43 \%$ do not consume alcohol and $57 \%$ do, and finally $64 \%$ do exercise and $36 \%$ do not.

\section{Instrument}

The SF-12 questionnaire. Used to evaluate health-related quality of life. Composed of twelve items, whose purpose is to provide a profile of the state of health, defining a positive and negative state of physical and mental health, by means of eight dimensions : physical function, physical role, body pain, mental health, general health, vitality, social function and emotional role (Alonso, Prieto, \& Anto, 2003). The reliability for the scale was 0.84 .

Academic Satisfaction. This scale is composed of 7 items that inquire into the level of student satisfaction with their academic experience. Participants are asked to respond using a Likert scale with 5 answer options, where 1 represents "strongly disagree" and 5 "strongly agree" (Lent et al., 2005). The reliability of the scale was 0.90 .

\section{Procedure}

The phase of the fieldwork began with a formal request sent to the principals of each school or faculty of the Universidad Autonoma de Coahuila in the Southeast unit, specifically in the municipalities of Saltillo and Arteaga. After the authorization of the principals, the participating schools were visited and the surveys were applied. Prior to the application of the surveys, general instructions were given to those in charge of the application, asking them to sign the letter of consent. 
The application took approximately 15 minutes to complete, including the time it took the survey takers to collect each survey.

\section{Analysis of results}

The analysis of the information was carried out using the statistical package for the social sciences (SPSS), first, the reliability for each scale was processed, second, the frequencies and percentages of the general data of the participants were analyzed, and finally the descriptive and chi-square statistics of each of the scales were analyzed.

\section{Results}

En la siguiente Table se observan las dimensiones de la calidad de vida relacionada con la salud, los puntajes más altos se presentan en la salud mental, salud general y vitalidad, mientras que las dimensiones con menor puntaje fueron el rol físico, función física y rol emocional.

\begin{tabular}{|l|c|r|r|r|r|}
\hline Dimensions & \multicolumn{1}{|c}{ n } & \multicolumn{1}{c}{ Average } & \multicolumn{1}{c|}{ DE } & Minimum & Maximum \\
\hline $\begin{array}{l}\text { Physical } \\
\text { function }\end{array}$ & 467 & 12.80 & 19.69 & 0 & 100 \\
\hline $\begin{array}{l}\text { Social } \\
\text { function }\end{array}$ & 467 & 23.27 & 25.11 & 0 & 75 \\
\hline Physical role & 467 & 8.51 & 15.21 & 0 & 100 \\
\hline $\begin{array}{l}\text { Emotional } \\
\text { Role }\end{array}$ & 467 & 16.76 & 23.29 & 0 & 100 \\
\hline $\begin{array}{l}\text { Mental } \\
\text { Health }\end{array}$ & 467 & 41.40 & 15.31 & 3 & 100 \\
\hline Body pain & 467 & 16.50 & 20.78 & 0 & 75 \\
\hline $\begin{array}{l}\text { General } \\
\text { health }\end{array}$ & 467 & 41.07 & 38.45 & 0 & 100 \\
\hline Vitality & 467 & 40.32 & 37.74 & 0 & 100 \\
\hline
\end{tabular}

Table 1 SF-12 Student Descriptions

The average scores show that college students are satisfied with their college careers, their class learning, and the topics in their field of study. And they regularly feel comfortable with the educational atmosphere, intellectual stimulation, satisfied with academic life and enjoy their class activities.

Reactive

\begin{tabular}{|l|r|r|r|}
\hline \multicolumn{1}{|c}{ Reactive } & \multicolumn{1}{c|}{ Average } & \multicolumn{1}{c|}{ DE } \\
\hline $\begin{array}{l}\text { I am satisfied with my decision to graduate } \\
\text { from my chosen university }\end{array}$ & 456 & 4.46 & .827 \\
\hline I like what I have learned in my classes & 458 & 4.30 & .865 \\
\hline $\begin{array}{l}\text { I am enthusiastic about the issues in my field } \\
\text { of expertise }\end{array}$ & 457 & 4.13 & .845 \\
\hline $\begin{array}{l}\text { I am comfortable with the educational } \\
\text { atmosphere in my field of expertise }\end{array}$ & 458 & 3.96 & .927 \\
\hline $\begin{array}{l}\text { I enjoy the level of intellectual stimulation of } \\
\text { each subject }\end{array}$ & 458 & 3.87 & .883 \\
\hline Overall I am happy with my academic life & 458 & 3.82 & .949 \\
\hline $\begin{array}{l}\text { Most of the time I am enjoying my class } \\
\text { activities }\end{array}$ & 458 & 3.75 & .906 \\
\hline
\end{tabular}

Table 2 Descriptive of the academic satisfaction scale
From the information in the following table, it was concluded that health-related quality of life differs according to the level of academic satisfaction reached by university students. In conclusion, there is an association between HRQoL and academic satisfaction.

\begin{tabular}{|c|c|c|c|c|c|}
\hline & \multicolumn{3}{|c|}{ Academic Satisfaction } \\
\hline & & & Low & High & Total \\
\hline \multirow{4}{*}{$\begin{array}{l}\text { Quality } \\
\text { of life } \\
\text { related to } \\
\text { health }\end{array}$} & \multirow[t]{2}{*}{ Low } & Count & 21 & 351 & 372 \\
\hline & & $\begin{array}{l}\% \quad \text { within } \\
\text { Academic } \\
\text { Satisfaction }\end{array}$ & $67.7 \%$ & $83.2 \%$ & $82.1 \%$ \\
\hline & \multirow[t]{2}{*}{ High } & Count & 10 & 71 & 81 \\
\hline & & $\begin{array}{l}\% \quad \text { within } \\
\text { Academic } \\
\text { Satisfaction }\end{array}$ & $32.3 \%$ & $16.8 \%$ & $17.9 \%$ \\
\hline \multirow{2}{*}{\multicolumn{2}{|c|}{ Total }} & Count & 31 & 422 & 453 \\
\hline & & $\begin{array}{l}\% \quad \text { within } \\
\text { Academic } \\
\text { Satisfaction }\end{array}$ & $100.0 \%$ & $100.0 \%$ & $100.0 \%$ \\
\hline
\end{tabular}

Pearson's Chi-square, 4.68 and $\mathrm{p} \leq .03$.

Table 3 HRQoL Chi-square and Academic Satisfaction Level

According to the information in Table 4, it could be observed that there is an association between the HRQoL level and cigarette consumption.

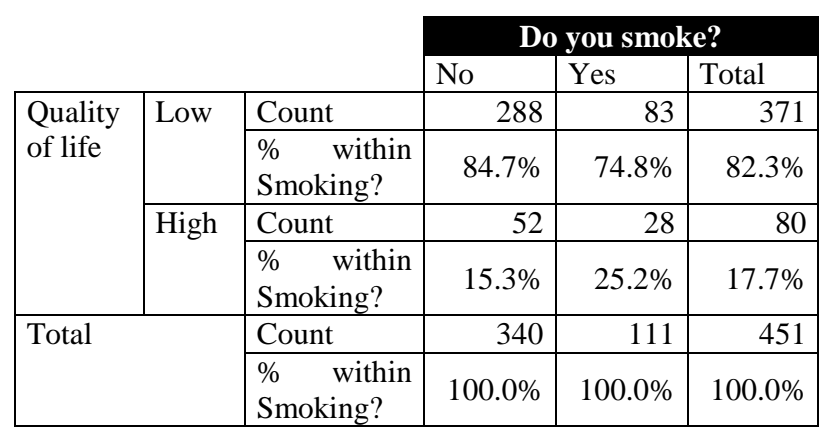

Pearson's Chi-square, 5.65 and $\mathrm{p} \leq .01$.

Table 4 Chi-square of HRQoL level and smoking

\section{Conclusions}

Generally speaking, it can be concluded that university students have optimum levels of health-related quality of life, they are perceived as being in good health, with a sense of peace, happiness and calm, with energy and enthusiasm. The weakest aspects of their quality of life are found in physical function, which refers to having limitations in physical activities including bathing or dressing due to a health problem, physical role, when problems with work or other daily activities occur as a result of their physical health, and emotional role, which refers to problems with work or other normal activities due to emotional problems. 
Likewise, it was concluded that the students present high levels of school satisfaction, which are reflected in their satisfaction with their chosen career, their taste for what they learn in class, their enthusiasm for the subjects of their field of specialization, their comfort in the educational environment, their intellectual stimulation, their academic life and their enjoyment of the class activities.

\section{References}

Alfaro, J., Guzmán, J., Reyes, F., García, C., Varela, J., \& Sirlopú, D. (2016). Satisfacción global con la vida y satisfacción escolar en estudiantes chilenos. Psykhe, 25(2), 1-14. https://doi.org/10.7764/psykhe.25.2.842

Alonso, J., Prieto, L., \& Anto, J. (2003). La versión española del SF-36 Health Survey (Cuestionario de Salud SF-36): un instrumento para la medida de los resultados clínicos. Medicina Clínica, 104. Recuperado de http://www.ser.es/wp-

content/uploads/2015/03/SF36_CUESTIONAR IOpdf.pdf

Blázquez, J., Chamizo, J., Cano, E., \& Gutiérrez, S. (2013). Calidad de vida universitaria: Identificación de los principales indicadores de satisfacción estudiantil. Revista de Educación, 362, 458-484. https://doi.org/10.4438/1988592X-RE-2013-362-238

Brito, T., \& Palacio, J. (2016). Calidad de vida, desempeño académico y variables sociodemográficas en estudiantes universitarios de Santa Marta-Colombia. Revista Duazary, 13(2), 131-141. Recuperado de https://revistas.unimagdalena.edu.co/index.php/ duazary/article/view/1719/1216

Cassaretto, M., Martínez, P., \& Tavera, M. (2020). Aproximación a la salud y bienestar en estudiantes universitarios: importancia de las variables sociodemográficas, académicas y conductuales. Revista de Psicología, 38(2), 499528.

https://doi.org/https://doi.org/10.18800/psico.20 2002.006

Chau, C., \& Vilela, P. (2017). Variables asociadas a la salud física y mental percibida en estudiantes universitarios de Lima. Liberabit. Revista de Psicología, 23(1), 89-102. https://doi.org/10.24265/liberabit.2017.v23n1.0 6
Díaz, S., Martínez, M., \& Zapata, A. (2017). Rendimiento académico y calidad de vida relacionada con la salud en estudiantes de odontología. Revista Salud Uninorte, 33(2), 139-151. Retrieved from https://www.redalyc.org/pdf/817/81753189008. pdf

Escobar-Puig, M., \& Rodríguez-Macías, J. C. (2018). Evaluación de la calidad de vida escolar en estudiantes de tercero de secundaria del estado de Baja California, México. Revista de Estudios y Experiencias En Educación, 17(33). https://doi.org/10.21703/rexe.20181733mescob ar6

Lara, N., Saldaña, Y., Fernández, N., \& Delgadillo, H. (2015). Salud, Calidad de Vida y entorno universitario en estudiantes mexicanos de una Universidad Pública. Hacia La Promoción de La Salud, 20(2), 102-117. https://doi.org/10.17151/hpsal.2015.20.2.8

Lima, M., Martínez, J., Guerra, M., Vargas, A., \& Lima, J. (2018). Factores relacionados con la calidad de vida en la adolescencia. Gaceta Sanitaria, $\quad 32(1), \quad 68-71$. https://doi.org/10.1016/j.gaceta.2016.06.016

Luna, J. F. (2012). Bienestar subjetivo y satisfacción escolar en la adolescencia. Universitat de Girona. Retrieved from https://www.tdx.cat/bitstream/handle/10803/11 7735/txls.pdf?sequence $=5$

Méndez, I., Namihira, D., Moreno, L., \& Sosa, C. (1990). El protocolo de investigación: Lineamientos para su elaboración y análisis (2nd ed.). México: Trillas.

Morales, M., \& Chávez, J. (2019). Satisfacción académica en estudiantes de nivel superior: variables escolares y personales asociadas. Revista Electrónica Sobre Cuerpos Académicos y Grupos de Investigación, 6(12), 1-21.

Pacheco, M., Michelena, M., Mora, R., \& Miranda, O. (2014). Calidad de vida relacionada con la salud en estudiantes universitarios. Revista Cubana de Medicina Militar, 43(2), 157-168. Retrieved from http://web.a.ebscohost.com.proxy.infosal.uadec. $\mathrm{mx} / \mathrm{ehost} / \mathrm{detail} / \mathrm{detail}$ ?vid=32\&sid=cc1d24705db7-45fe-93cc-9f19d7297511\%40sdc-vsessmgr01\&bdata=Jmxhbmc9ZXMmc210ZT1la G9zdC1 saXZl\#AN=99329113\&db=lth

GARCÍA-GARCÍA，Jesús Alberto, CUFARFÁN-LÓPEZ, Julio, FARIAS-BRACAMONTES, Juan Carlos and GARCÍACONTRERAS, Laura Patricia. Quality of life related with health and academic satisfaction of university students ECORFAN JournalRepublic of Guatemala. 2020 
Pascual, I. (2007). Análisis de la satisfacción del alumno con la docencia recibida: un estudio con modelos jerárquicos lineales. Revista Electrónica de Investigación y Evaluación Educativa, 13(1), 127-138. https://doi.org/https://doi.org/10.7203/relieve.1 3.1.4216

Reig, A., Cabrero, J., Ferrer, R., \& Richart, M. (2001). La calidad de vida y el estado de salud de los estudiantes universitarios (1st ed.). España: Universidad Alicante.

Tacca, D., Tacca, A., \& Cuarez, R. (2020). Inteligencia emocional del docente $\mathrm{y}$ satisfacción académica del estudiante universitario. Revista Digital de Investigación En Docencia Universitaria, 14(1), 1-16. https://doi.org/10.19083/ridu.2020.887

Terrazas, B., \& Almeida, R. (2020). Análisis de los principales indicadores de satisfacción estudiantil en la calidad de vida universitaria en las universidades privadas. Revista Perspectivas, 23(45), 7-23. Retrieved from http://www.scielo.org.bo/scielo.php?pid=S1994 $-37332020000100002 \&$ script=sci_arttext

Vergara, J., Del Valle, M., Diaz, A., \& Pérez, M. (2018). Adaptación de la Escala de Satisfacción Académica en Estudiantes Universitarios Chilenos. Psicologia Educativa, 24(2), 99-106. https://doi.org/10.5093/psed2018a15 